\title{
Cover Crop and Fertility Effects on Escherichia coli Abundance in a Composted Poultry Litter-Amended Silt Loam Soil
}

\author{
Sait Sarr, ${ }^{1}$ Mark Coyne ${ }^{D},{ }^{2}$ Maheteme Gebremedhin $\left(\mathbb{D},{ }^{3}\right.$ Avinash Topè, ${ }^{3}$ and Shreya Patel ${ }^{3}$ \\ ${ }^{1}$ School of Urban and Public Affairs, University of Louisville, Louisville, KY 40208, USA \\ ${ }^{2}$ Department of Plant and Soil Sciences, University of Kentucky, Lexington, KY 40546, USA \\ ${ }^{3}$ College of Agriculture, Communities, and the Environment, Kentucky State University, Frankfort, KY 40601, USA
}

Correspondence should be addressed to Maheteme Gebremedhin; maheteme.gebremedhin@kysu.edu

Received 18 October 2019; Accepted 23 January 2020; Published 20 February 2020

Academic Editor: Amaresh K. Nayak

Copyright ( $\odot 2020$ Sait Sarr et al. This is an open access article distributed under the Creative Commons Attribution License, which permits unrestricted use, distribution, and reproduction in any medium, provided the original work is properly cited.

\begin{abstract}
Soil conservation practices such as cover crops can improve crop production, soil quality, and water quality. Cover crops can also influence soil microbial growth and activity. Cover cropped and manured soils can potentially store and transmit fecal bacteria (e.g., E. coli) to surface water if runoff and subsurface seepage occur. While many studies have shown the soil health benefits of cover crops, fewer studies have evaluated the extent to which cover crops influence the abundance of potential waste-borne pathogens. A two-year study (2015-2017) was conducted on a limited-resource farm in Logan County, Kentucky, USA, to quantify the abundance of the fecal indicator Escherichia coli (E. coli) bacteria (as a proxy for fecal coliforms) in treatments with and without cover crops or composted poultry litter. The cover crop consisted of a cereal rye (Secale cereale L.), Austrian winter pea (Pisum sativum L.), and crimson clover (Trifolium incarnatum L.) mix. Summer crops consisted of a no-till maize (Zea mays L.) - soybean (Glycine max L.) rotation. Soil samples were taken before and after each summer crop season and assessed to detect and enumerate E. coli. At the end of the study period, no significant treatment differences in the E. coli abundance in soil were detected $\left(\mathrm{ca} .10^{4} \mathrm{CFU} \cdot \mathrm{g}^{-1}\right)(p>0.05)$. However, season/time was a significant factor $(p<0.05)$. We conclude that the background E. coli already present in soil was sufficiently high, inhibiting the detection of the influence of added composted litter. These indigenous $E$. coli were unaffected by cover crop and nutrient management but did fluctuate on a seasonal basis.
\end{abstract}

\section{Introduction}

Conservation management practices can improve crop production and soil quality $[1,2]$. There are numerous benefits derived from using cover crops, including protecting the soil from erosion $[3,4]$, enhancing soil mineralization [2,5], suppressing weeds and soilborne diseases [6], more efficient nutrient cycling [7], and improving soil quality and yield $[8,9]$. From a microbial perspective, cover crops improve soil aeration, increase water holding capacity, provide available carbon (C), and enhance soil microbial growth and activity [10]. However, soil can be a reservoir for transmitting fecal pathogens if use of manure is one of the conservation practices [11], and soil-borne pathogens can contaminate farm produce, particularly vegetables, at the crop production level.
Efficient integration and application processes along with cover cropping in the long-term and sustainable use of animal manure can control pathogens [12], but there have been few studies investigating how cover crops influence the persistence of fecal bacteria in soil. Schutter et al. [13] observed that season was the key determinant of microbial community structure, rather than winter or summer cover crop use; E. coli numbers declined as temperatures fell. Jiang et al. [14] also found rapid decline in E. coli numbers in manured soils at lower temperatures. Other factors influencing the presence and survival of fecal bacteria include soil type, $\mathrm{pH}$, manure application rate, nutrient availability, and competition [15]. Reed-Jones et al. [11] showed that time, bacterial species, temperature, precipitation, and tillage influenced the relationship between cover crops and bacterial numbers in soils. Cover crop was a factor in E. coli 
persistence in one year, but elevated populations did not persist year-to-year.

Untreated manure can carry harmful bacteria (e.g., pathogens) to soil, which can survive for weeks and transfer to the edible crop parts with time [16]. Land-application of animal manure also enables bacterial pathogens to reach groundwater and adversely affect ecosystem and human health [17-20]. Though it is normally a benign commensal organism and used as a proxy for enteric pathogens, several E. coli strains are pathogenic and can cause severe hemorrhagic colitis and hemolytic uremia in humans [15, 21-23].

Our previous research suggests that combining cover crops and poultry litter has additive effects on soil nitrogen (N) mineralization [2] and crop biomass [24]. The objective of this study was to quantify abundance of fecal indicator bacteria (E. coli-a proxy for fecal coliforms and more serious pathogens) in different poultry litter compost-amended and chemical fertilizer treatments, with and without cover crops. The study was conducted over a 2 -year period. Based on previous research, our hypothesis was that cover crops would have no effect on the abundance and survival of fecal indicator bacteria.

\section{Materials and Methods}

2.1. Research Site and Experiment Design. Starting in Fall 2015, a 0.32 ha study site was established at a farm in Logan County, Kentucky $\left(36.88^{\circ} \mathrm{N} ; 86.60^{\circ} \mathrm{W}\right.$, altitude $\left.183 \mathrm{~m}\right)$. The site has a temperate humid continental climate with mean annual temperature and precipitation ranging between 7 and $21^{\circ} \mathrm{C}$ and 991 to $1524 \mathrm{~mm}$, respectively (Figure 1). The area is frost-free much of the year (154-219 frost-free days) with an average growing season from May to September, and an average temperature of $22^{\circ} \mathrm{C}$ during the growing season (Figure 1). According to USDA soil taxonomy, the soil is classified as Crider silt loam (fine-silty, mixed, active, mesic Typic Paleudalfs), well-drained with 2-6\% slopes. During the study period, maize (Zea maize L.) and soybean (Glycine $\max \mathrm{L}$.) were grown in a rotation with a cover crop mix of cereal rye (Secale cereale), Austrian winter pea (Pisum sativa), and crimson clover (Trifolium incarnatum).

The field experiment was a randomized complete block design with four replications (blocks). Six treatments were randomly applied to plots within blocks: (1) an unamended control; (2) cover crops (CC); (3) poultry litter compost (PL); (4) poultry litter compost and cover crop (PL + CC); (5) synthetic fertilizer (NPK); and (6) fertilizer and cover crop $(\mathrm{NPK}+\mathrm{CC})$. Poultry litter compost was applied on an N-rate basis, and chemical fertilizers consisting of synthetic compounds were applied at established rates recommended by the University of Kentucky's Cooperative Extension Service [2, 26]. Poultry litter compost was applied at a rate of $1.78 \mathrm{Mg} \cdot \mathrm{ha}^{-1}$ in Spring 2016 when the summer crop was soybean and 26.3 Mg.ha ${ }^{-1}$ in Spring 2017 when the summer crop was maize.

2.2. Soil Collection and Laboratory Methods. Twenty-four soil core samples (consisting of four composite soil cores each) were collected from surface soil $(0-15 \mathrm{~cm}$ depth) prior to treatment applications in Spring and at harvest in Fall each year (Table 1). Soil cores were obtained using a soil core sampler (inner diam $=7 \mathrm{~cm}$ ), and samples were taken from between rows within each treatment plot. Plant residues and nonsoil materials were removed, and large soil clods were broken by hand.

The soil samples, placed on ice, were transported to Kentucky State University for further analysis. Microbial analyses started within $24 \mathrm{~h}$ of field data collection. The soil samples were analyzed to detect and enumerate E. coli. Approximately, $5 \mathrm{~g}$ of soil was weighed and added to $10 \mathrm{ml}$ of sterile saline solution. One millilitre of this mixture was used to perform a serial dilution up to 1000 folds. One millilitre of the mixture from the 1000 -fold dilution was used to inoculate triplicate plates of $3 \mathrm{M}^{\mathrm{TM}}$ Petrifilms to test for the presence of E. coli. The Petrifilms were incubated at $37^{\circ} \mathrm{C}$ for 48 hours, after which positive colonies on each Petrifilm were enumerated. E. coli in the poultry litter compost was also tested by a similar procedure prior to application. All results are expressed as colony forming units per gram of soil or poultry litter compost on a dry weight basis. The values of the fecal bacteria (E. coli) count were log transformed for statistical purposes. For reference purposes, baseline samples were taken in Fall 2015 before the start of the study.

2.3. Statistical Methods. Treatment effects on fecal bacterial (E. coli) numbers with time were assessed by comparing treatments, including the cover crop treated plots and the noncover crop treated plots. We also compared treatment means between sampling periods in a given year. A one-way analysis of variance (ANOVA) to compare means was used based on Tukey's test (a single-step, multiple comparison statistical test used to find means that are significantly different from each other). A significant $F$-test was declared at $p<0.05$. Analysis was performed using SPSS (IBM SPSS Statistics version 22).

\section{Results and Discussion}

The site had a baseline mean E. coli count of $6.3 \times 10^{4} \mathrm{CFU} \cdot \mathrm{g}^{-1}$ soil in Fall 2015 prior to planting cover crops. This was attributed to the site having been fertilized with poultry litter for the past five years (personal communication with the owner). A newly poultry litter-amended silt loam soil in Kentucky studied by Cooprider and Coyne [27] had soil fecal coliform numbers between $2 \times 10^{3}$ and $6.4 \times 10^{4} \mathrm{CFU} \cdot \mathrm{g}^{-1}$, while a similar unamended soil had fecal coliform numbers of $1-2 \times 10^{2} \mathrm{CFU} \cdot \mathrm{g}^{-1}$ [28]. The litter from the poultry source throughout the study was composited rather than fresh. Consequently, the E. coli count in the poultry litter compost itself prior to application was only $66 \mathrm{CFU} \cdot \mathrm{g}^{-1}$ in 2016 and $6.3 \times 10^{3} \mathrm{CFU} \cdot \mathrm{g}^{-1}$ in 2017. These numbers are quite low relative to the reported values of $E$. coli in fresh poultry litter $\left(\mathrm{ca} \cdot 10^{7} \cdot \mathrm{g}^{-1}\right)$ [29]. It is reasonable to expect low E. coli count in composted and dried material. From the perspective of land application a decline in E. coli count is expected, thus making it a safer option to fresh litter. Considering treatments without poultry litter compost 


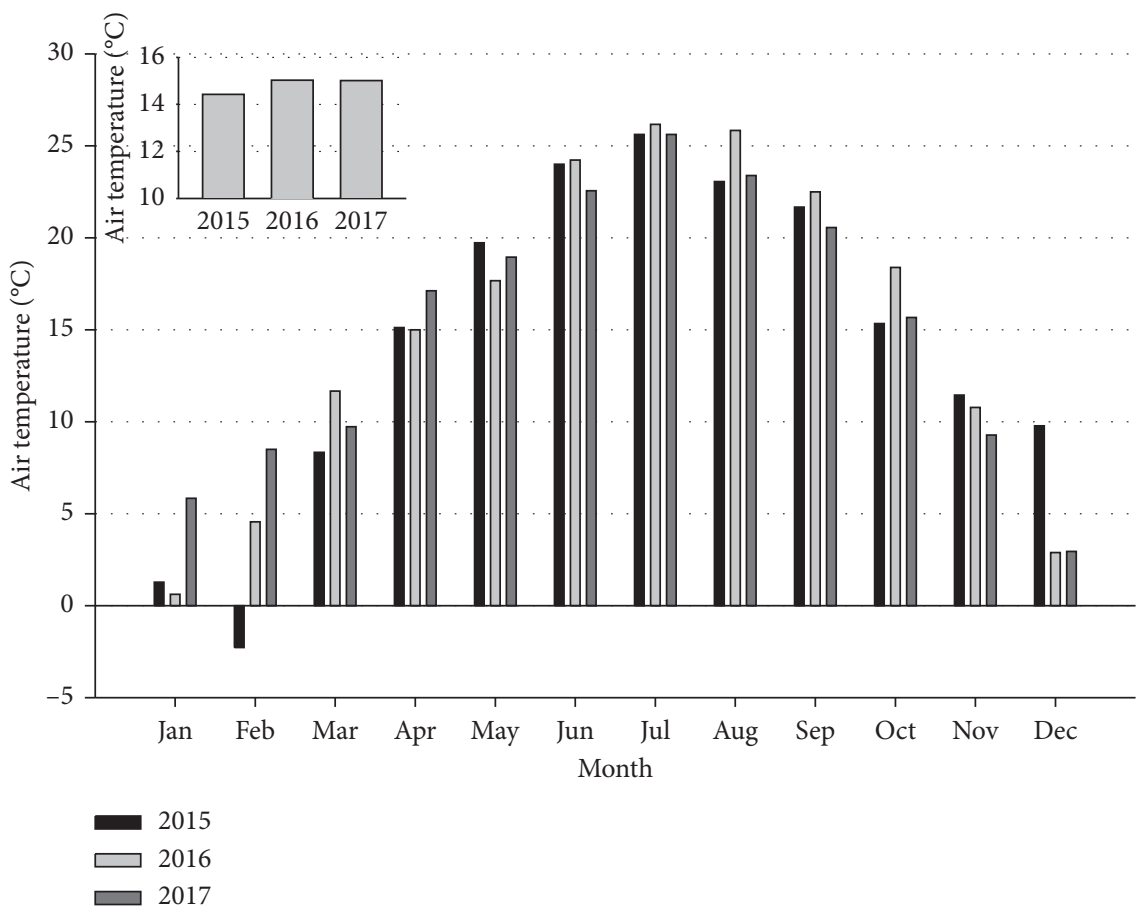

(a)
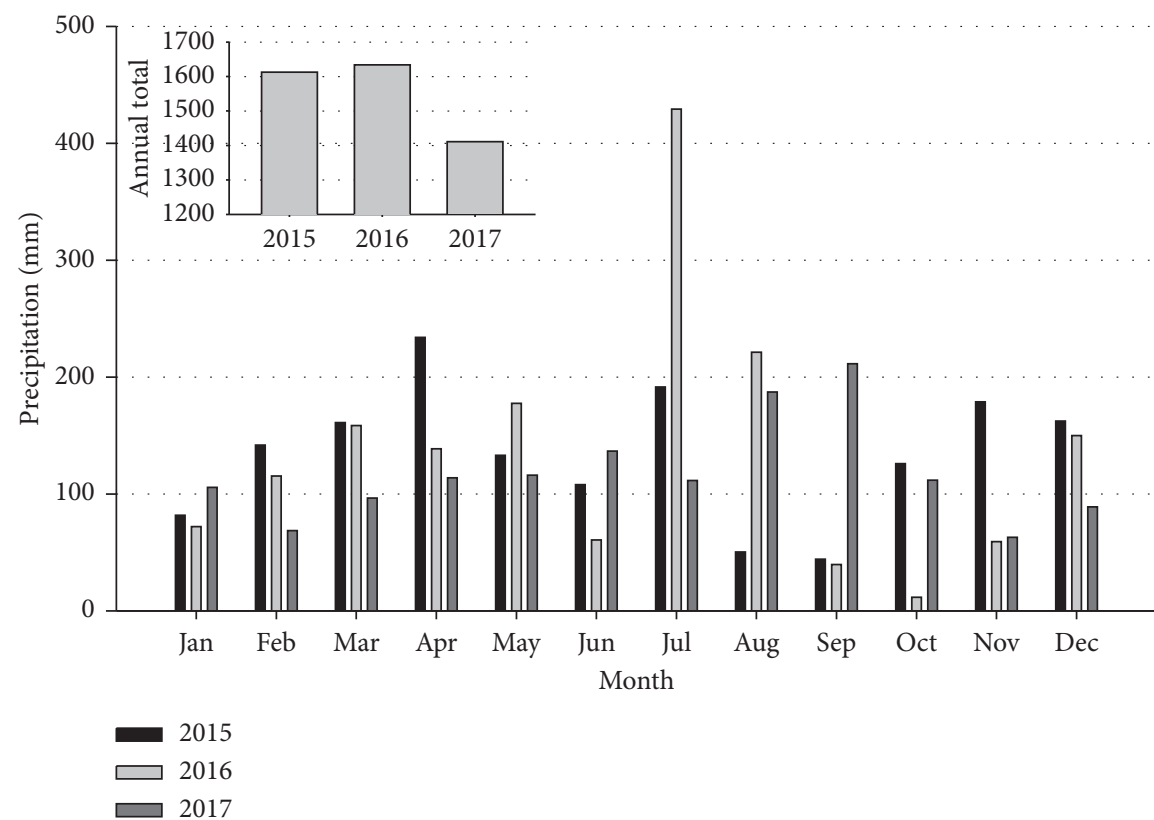

(b)

FIGURE 1: Average monthly air temperature (yearly average inset) and precipitation (yearly average inset) at the Logan farm for 2015, 2016, and 2017. Precipitation records are from the Logan County Mesonet Weather Data $\left(38.12^{\circ} \mathrm{N} ; 84.88^{\circ} \mathrm{W}\right)$ [25].

amendment each year had statistically the same E. coli counts as poultry litter compost-treated soils, we can conclude that poultry litter compost amendment in and of itself did not change the E. coli concentration either year. In 2016, the litter compost application rates would have changed soil E. coli concentrations $<0.01 \%$ and in $2017<0.5 \%$. Consequently, our study principally evaluated how adding the poultry litter composts itself and cover crops influenced the resident soil E. coli concentration.
In Spring 2016, neither poultry litter compost nor cover crop treatment were significant factors $(p>0.05$; Figure 1) for $E$. coli concentration. E. coli counts among all treatments sharply decreased from the Fall 2015 assessment. In contrast, E. coli counts significantly increased from Spring 2016 (before poultry litter compost application) to Fall 2016 $(p<0.05$; Figure 1$)$. The greatest increase in E. coli count $\left(+3.1 \log \mathrm{CFU} \cdot \mathrm{g}^{-1}\right.$ soil) occurred with the NPK + CC treatment, and the least increase $\left(+2.2 \log \mathrm{CFU} \cdot \mathrm{g}^{-1}\right.$ soil) occurred 
TABLE 1: Soil sampling, and cover crop planting and termination dates.

\begin{tabular}{|c|c|c|c|c|}
\hline Year & Season & $\begin{array}{c}\text { Cover crop/main } \\
\text { crop }\end{array}$ & $\begin{array}{l}\text { Planting } \\
\text { date }\end{array}$ & $\begin{array}{c}\text { Harvest/ } \\
\text { termination } \\
\text { date }\end{array}$ \\
\hline $\begin{array}{l}2015- \\
2016\end{array}$ & Fall & $\begin{array}{l}\text { Mix of cereal rye, } \\
\text { Austrian winter } \\
\text { pea, and crimson } \\
\text { clover }\end{array}$ & $\begin{array}{c}15 \\
\text { October } \\
2015\end{array}$ & 5 May 2016 \\
\hline \multirow[b]{2}{*}{$\begin{array}{l}2016- \\
2017\end{array}$} & Summer & Soybean & $\begin{array}{l}25 \text { May } \\
2016\end{array}$ & $\begin{array}{l}26 \text { October } \\
2016\end{array}$ \\
\hline & Fall & $\begin{array}{c}\text { Mix of cereal rye, } \\
\text { Austrian winter } \\
\text { pea, and crimson } \\
\text { clover }\end{array}$ & $\begin{array}{l}27 \\
\text { October } \\
2016\end{array}$ & 5 May 2017 \\
\hline \multirow[b]{2}{*}{$\begin{array}{l}2017- \\
2018\end{array}$} & Summer & Field maize & $\begin{array}{l}7 \text { June } \\
2017\end{array}$ & $\begin{array}{l}25 \text { October } \\
2017\end{array}$ \\
\hline & Fall & $\begin{array}{c}\text { Mix of cereal rye, } \\
\text { Austrian winter } \\
\text { pea, and crimson } \\
\text { clover }\end{array}$ & $\begin{array}{c}26 \\
\text { October } \\
2017\end{array}$ & 30 May 2018 \\
\hline
\end{tabular}

with the PL + CC treatment. Neither cover crop nor poultry litter compost treatment was significant. Other studies $[11,18,28]$ found a strong correlation between E. coli persistence in Spring and Fall sampling periods, with weather-related factors such as temperature and precipitation causing significant declines during the season. So, the decline from Fall 2015 to Spring 2016 was predictable. The increase in E. coli counts during the season was not predicted. In a no-till practice, cover crops can conserve soil moisture and serve as insulators that buffer soil temperature fluctuations [30, 31]. Spring 2016 was colder than in 2017, while the months from February to August were wetter (Figure 1), and this may account for the resilience of the resident soil $E$. coli present from prior years (Figure 2).

In 2017, E. coli counts usually declined among all treatments from Spring 2017 to Fall 2017 (Figure 3). The greatest decline in the E. coli $\left(-1.3 \log \mathrm{CFU} \cdot \mathrm{g}^{-1}\right.$ soil) counts occurred with the PL + CC treatment, but differences among treatments were not statistically significant $(p>0.05)$. The decline was not nearly as considerable as one would expect from freshly added fecal bacteria as demonstrated by ReedJones et al. [11] and Stoddard et al. [18] in which nondetectable baseline E. coli values were reached several months after application.

The E. coli count in Spring 2017 was much higher than in Spring 2016 regardless of treatment. January and February 2016 were substantially colder than the corresponding months in 2017, which could account for the difference in persistence. Despite the higher litter compost application rate and E. coli counts, the trend was for E. coli counts to slightly decline with time in 2017 in contrast to 2016 when counts increased; 2016 had slightly more precipitation than 2017 and substantially more in the key summer months of July and August, which may account for the different trends.

The absence of a treatment effect and the similarity of $E$. coli counts in soil without any added poultry litter compost

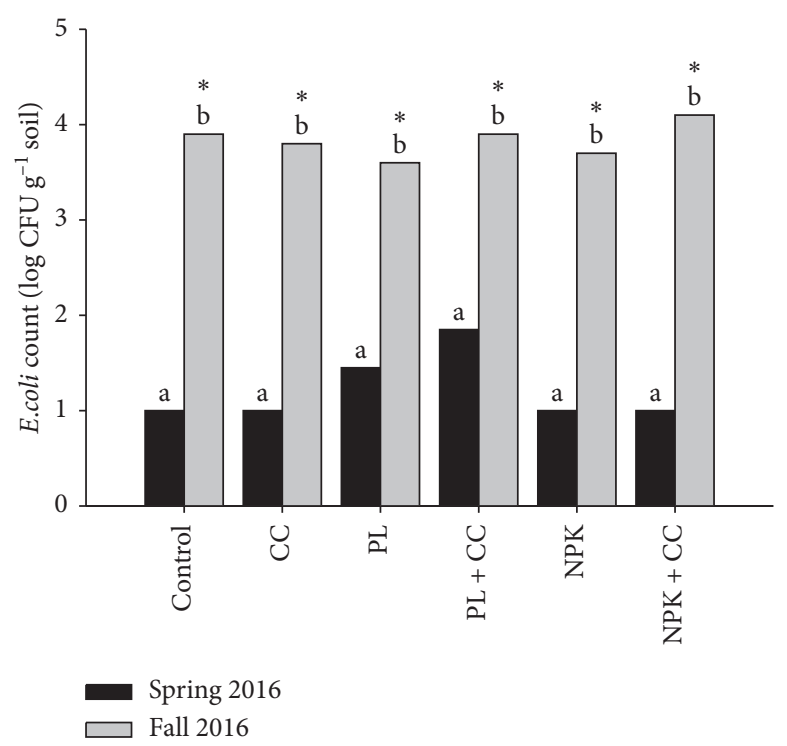

FIgURE 2: Treatment effects of poultry litter compost (PL) and chemical fertilizers (NPK) with or without cover crops (CC) and an unamended control on the numbers of E. coli (log CFU.g ${ }^{-1}$ soil) in Spring and Fall of 2016. Different letters above each bar indicate significant differences between treatments within a sample period at $p<0.05$. Within a treatment, asterisks indicate significant difference between sampling periods (Spring and Fall in a given year) at $(p<0.05)$. Only sample season was a significant effect.

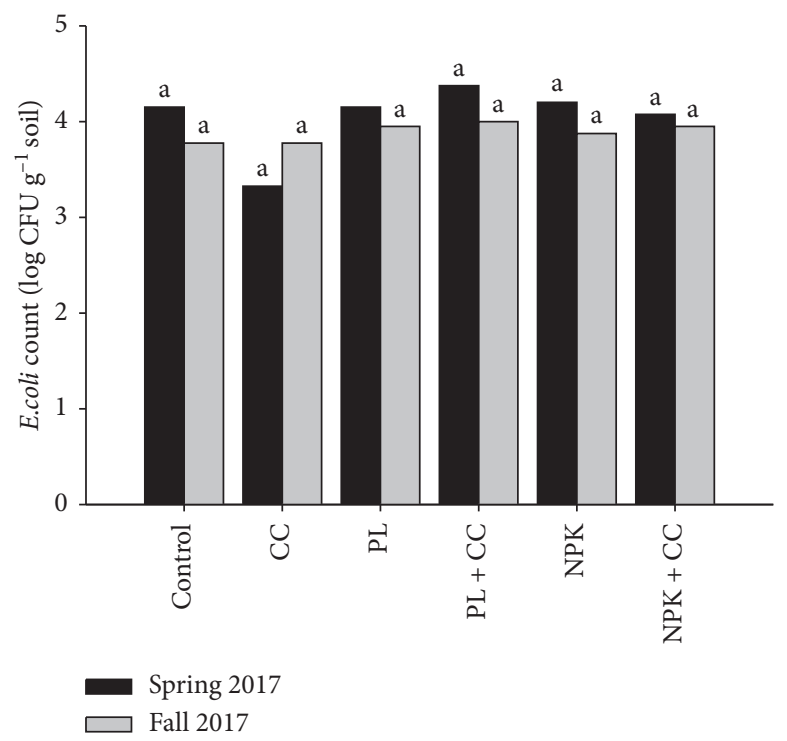

FIgURE 3: Treatment effects of poultry litter compost (PL) and chemical fertilizers (NPK) with or without cover crops (CC) and unamended control on the numbers of E. coli (log CFU.g ${ }^{-1}$ soil) in Spring and Fall of 2017. Different letters above each bar indicate significant differences between treatments within a sample period at $p<0.05$. There were no significant time or treatment effects.

strongly suggest seasonal changes in the indigenous soil $E$. coli rather than an influence of the $E$. coli in poultry litter compost. Cover crop presence had no effect. The reduction in soil E. coli from 2015 to 2017 may suggest a trend to lower 
background E. coli from season to season as poultry litter compost is added at agronomically relevant rates instead of fresh litter. Litter effects on the soil microbial community persisted for as long as 4 years in a study with poultry litter amended cotton in Arizona [32] and, overall, increased diversity of the resident population even as the culturable fecal coliforms in the soil became undetectable. The benefits of poultry litter compost addition on the soil microbial population, therefore, appear to outweigh the potential detriment of adding fecal organisms.

\section{Conclusion}

Cover crops had no influence on E. coli dynamics. There was no significance to the combined effects of cover crops and poultry litter compost compared to the use of either or alone on the number of fecal bacteria (e.g., E. coli) in either year (2016 and 2017). The effect of the crop treatment could have been limited by the interaction of the different cover crop species (soybean vs. maize), precipitation, temperature, and time. The fluctuation in the number of $E$. coli was statistically significant between sampling periods in a given year, but the time between sampling periods to detect $E$. coli was also long. Many interactions that play a role in the population dynamics of $E$. coli could have been missed between the Spring and Fall sampling periods. Prior work has shown that temperature and moisture (rainfall) are key drivers in the population dynamics of $E$. coli and that also appears to be demonstrated in this study. Cover crops neither increased nor decreased the soil E. coli counts.

\section{Data Availability}

Data used for this study can be obtained upon request made to Maheteme Gebremedhin (Maheteme.gebremedhin@ kysu.edu).

\section{Disclosure}

The content is solely the responsibility of the authors and does not necessarily represent the official views of Kentucky NRCS.

\section{Conflicts of Interest}

The authors declare no conflicts of interest.

\section{Acknowledgments}

This study was fully supported by Kentucky's NRCS Conservation Innovation Program (Grant no. 68-5C16-155251). Sait Sarr acknowledges the graduate assistantship from the College of Agriculture, Communities, and the Environment at Kentucky State University. The authors extend their gratitude to the following individuals for their assistance during the design, field sampling, data collection, and laboratory analysis: Jason Simmons, Tierra FreemanTaylor, Edwin Chavous, Ronald Bunton, and Leroy Ballew.

\section{References}

[1] N. K. Fageria, V. C. Baligar, and B. A. Bailey, "Role of cover crops in improving soil and row crop productivity" Communications in Soil Science and Plant Analysis, vol. 36, no. 1920, pp. 2733-2757, 2005.

[2] S. Sarr, M. Gebremedhin, M. Coyne, A. Topè, K. Sistani, and S. Lucas, "Do conservation practices bring quick changes to key soil properties for resource-limited farmers?" Journal of the Kentucky Academy of Science, vol. 80, no. 1, pp. 1-11, 2019.

[3] B. E. Fronning, K. D. Thelen, and D.-H. Min, "Use of manure, compost, and cover crops to supplant crop residue carbon in corn stover removed cropping systems," Agronomy Journal, vol. 100, no. 6, pp. 1703-1710, 2008.

[4] M. E. Schipanski, M. Barbercheck, M. R. Douglas et al., "A framework for evaluating ecosystem services provided by cover crops in agroecosystems," Agricultural Systems, vol. 125, pp. 12-22, 2014.

[5] J. Eriksen, "Gross sulphur mineralisation-immobilisation turnover in soil amended with plant residues," Soil Biology and Biochemistry, vol. 37, no. 12, pp. 2216-2224, 2005.

[6] S. J. Park, F. Baysal-Gurel, K. Everts, C. Smart, S. Miller, and B. Mcspadden-Gardener, "Plant disease suppression by single vs. mixed species cover crops," 2012, http://eorganic.info/ node/7961.

[7] K. R. Baldwin and N. G. Creamer, "Cover crops for organic farms," G-659W-03, North Carolina State University, College of Agriculture and Life Sciences, North Carolina Cooperative Extension Service, Raleigh, NC, USA, 2006.

[8] P. Mader, A. Fliessbach, D. Dubois, L. Gunst, P. Fried, and U. Niggli, "Soil fertility and biodiversity in organic farming," Science, vol. 296, no. 5573, pp. 1694-1697, 2002.

[9] C. Crecchio, A. Gelsomino, R. Ambrosoli, J. L. Minati, and P. Ruggiero, "Functional and molecular responses of soil microbial communities under differing soil management practices," Soil Biology and Biochemistry, vol. 36, no. 11, pp. 1873-1883, 2004.

[10] C. Ramos, L. Molbak, and S. Molin, "Bacterial activity in the rhizosphere analyzed at the single-cell level by monitoring ribosome contents and synthesis rates," Applied and Environmental Microbiology, vol. 66, no. 2, pp. 801-809, 2000.

[11] N. L. Reed-Jones, S. C. Marine, K. L. Everts, and S. A. Micallef, "Effects of cover crop species and season on population dynamics of Escherichia coli and Listeria innocua in soil," Applied and Environmental Microbiology, vol. 82, no. 6, pp. 1767-1777, 2016.

[12] A. M. Topè, A. Hitter, and P. F. Rogers, "Evaluation of good agricultural practice (GAP) compliance by small farmers in KY: assessing microbial quality of produce," Journal of Agriculture and Environmental Sciences, vol. 3, no. 4, pp. 29-49, 2014.

[13] M. Schutter, J. Sandeno, and R. Dick, "Seasonal, soil type, and alternative management influences on microbial communities of vegetable cropping systems," Biology and Fertility of Soils, vol. 34, no. 6, pp. 397-410, 2001.

[14] X. Jiang, J. Morgan, and M. P. Doyle, "Fate of Escherichia coli O157: H7 in manure-amended soil," Applied and Environmental Microbiology, vol. 68, no. 5, pp. 2605-2609, 2002.

[15] R. Jamieson, R. S. Gordon, K. E. Sharples, and G. Madani, "Movement and persistence of fecal bacteria in agricultural soils and subsurface drainage water: a review," Canadian Biosystem Engineering, vol. 44, pp. 1.1-1.9, 2002.

[16] A. N. Pell, "Manure and microbes: public and animal health problem?" Journal of Dairy Science, vol. 80, no. 10, pp. 2673-2681, 1997. 
[17] S. W. McMurry, M. S. Coyne, and E. Perfect, "Fecal coliform transport through intact soil blocks amended with poultry manure," Journal of Environmental Quality, vol. 27, no. 1, pp. 86-92, 1998.

[18] C. S. Stoddard, M. S. Coyne, and J. H. Grove, "Fecal bacteria survival and infiltration through a shallow agricultural soil: timing and tillage effects," Journal of Environment Quality, vol. 27, no. 6, pp. 1516-1523, 1998.

[19] J. V. Gagliardi and J. S. Karns, "Leaching of Escherichia coli O157: H7 in diverse soils under various agricultural management practices," Applied and Environmental Microbiology, vol. 66, no. 3, pp. 877-883, 2000.

[20] A. M. Truhlar, A. E. Salvucci, M. T. Walter, L. D. Warnick, A. G. Hay, and T. S. Steenhuis, "Effects of manure-application practices on curli production by Escherichia coli transported through soil," Environmental Science \& Technology, vol. 49, no. 4, pp. 2099-2104, 2015.

[21] S. Ratnam, S. B. March, R. Ahmed, G. S. Bezanson, and S. Kasatiya, "Characterization of Escherichia coli serotype O157: H7," Journal of Clinical Microbiology, vol. 26, no. 10, pp. 2006-2012, 1988.

[22] R. Tauxe, "Emerging foodborne diseases: an evolving public health challenge," Emerging Infectious Diseases, vol. 3, no. 4, pp. 425-434, 1997.

[23] Centers for Disease Control (CDC), "Public health dispatch: outbreak of Escherichia coli 0157:H7 and Campylobacter among attendees of the Washington county fair-New York," Morbidity Mortality Weekly Report, vol. 48, no. 36, pp. 803805, 1999.

[24] M. Gebremedhin, S. Sarr, M. Coyne, K. R. Sistani, and J. Simmons, "The combined influence of cover crops and manure on maize and soybean yield in a Kentucky silt loam soil," Sustainability, vol. 11, no. 21, p. 6058, 2019.

[25] Kentucky Mesonet, 2017, http://www.kymesonet.org/ historical_data.php.

[26] UK Cooperative Extension Service, 2018-2019 Nutrient and Lime Recommendations AGR-1, University of Kentucky, College of Agriculture, Cooperative Extension Service, Lexington, KY, USA, 2018.

[27] M. A. Cooprider and M. S. Coyne, "Do cover crop residue and no-till increase poultry litter runoff?" in Agronomy Notes, vol. 31, University of Kentucky Cooperative Extension Service, Lexington, KY, USA, 1999.

[28] A. Xu, R. L. Buchanan, and S. A. Micallef, "Impact of mulches and growing season on indicator bacteria survival during lettuce cultivation," International Journal of Food Microbiology, vol. 224, pp. 28-39, 2016.

[29] Q. Zhai, M. S. Coyne, and R. I. Barnhisel, "Mortality rates of fecal bacteria in subsoil amended with poultry manure," Bioresource Technology, vol. 54, no. 2, pp. 165-169, 1995.

[30] T. O. West and W. M. Post, "Soil organic carbon sequestration rates by tillage and crop rotation," Soil Science Society of America Journal, vol. 66, no. 6, pp. 1930-1946, 2002.

[31] R. P. Mathew, Y. Feng, L. Githinji, R. Ankumah, and K. S. Balkcom, "Impact of no-tillage and conventional tillage systems on soil microbial communities," Applied and Environmental Soil Science, vol. 2012, Article ID 548620, 10 pages, 2012.

[32] J. P. Brooks, H. Tewolde, A. Adeli et al., "Effects of subsurface banding and broadcast of poultry litter and cover crop on soil microbial populations," Journal of Environmental Quality, vol. 47 , no. 3 , pp. 427-435, 2018. 